Ao distanciar o foco acadêmico das necessidades e interesses discentes, a escola corre o risco de tornar-se um quisto cultural. Já no início do século XX, Dewey e outros filósofos propunham soluções para a educação escolar ante as mudanças da sociedade urbano-industrial e a construção histórico-social da juventude e da adolescência, cuja identidade se delineava como tímido ensaio. Por isso, entre outros caminhos (agora para os educadores), é preciso estudar e incentivar o engajamento dos alunos na escola, e poder pensar nesse ambiente como a ágora, local de prática da cidadania, construção e troca de conhecimento das mais diversas áreas na polis. Sem a vontade do aluno, que surge, no âmago de cada um, ao mesmo tempo como fator e efeito da dinâmica social, não se efetivam o processo educativo ou a aprendizagem.

DIOGO ACIOLI LIMA

aciolidiogo@gmail.com

IVAR CÉSAR OLIVEIRA DE VASCONCELOS

ivcov@hotmail.com

CANDIDO ALBERTO GOMES

clgomes@terra.com.br

Pesquisadores da Cátedra Unesco de Juventude, Educação e Sociedade da Universidade Católica de Brasília

\title{
HISTÓRIAS ÍNTIMAS: SEXUALIDADE E EROTISMO NA HISTÓRIA DO BRASIL
}

MARY DEL PRIORE

SÃO PAULO: PLANETA, 2011. 254 P.

É quase desnecessário afirmar que uma discussão sobre sexualidade, erotismo e pudor não pode prescindir de um debate sobre relações de gênero. É desse assunto que trata Mary del Priore em seu novo livro, Histórias íntimas: sexualidade e erotismo na história do Brasil. Novamente, a prestigiada historiadora carioca brinda-nos com um tema, no mínimo curioso, cujo conteúdo é antecedido por um prefácio escrito pelo saudoso Moacyr Scliar.

Se o título do livro aguça o nosso interesse pelo seu conteúdo, a sua capa não nos menos instiga. Nela, a imagem de uma enorme abertura de fechadura nos leva a uma série de impressões: a quebra da privacidade por um curioso que, por aquele orifício, observa pessoas em situações de intimidade; o desejo feminino aprisionado por um cinto de castidade posto por um marido cioso em cuidar de sua honra; uma metáfora da genitália feminina, uma fenda que, segundo os pregadores barrocos, era “porta do inferno e entrada do Diabo" (2011, p. 32). 
Ao transitar por cenários políticos, econômicos e culturais que marcaram a nossa história, Mary del Priore discute como os conceitos e os padrões de comportamentos e de beleza foram construídos e reconstruídos até chegar aos que consideramos hoje. Com um texto capaz de prender a nossa atenção, como assim se expressou Scliar, ela nos explica como sexualidade e erotismo deixaram de ser assuntos evitados e se tornaram temas dos mais comentados pela sociedade narcisista e confessional em que vivemos.

Como as palavras e os conceitos mudam no tempo e no espaço, a autora inicia sua discussão comentando que "a noção de intimidade no mundo dos homens entre os séculos XVI e XVIII se diferencia profundamente daquela que é a nossa no início do século XXI” (2011, p. 13). Naquela época, como a vida cotidiana era regulada por leis imperativas, as práticas relacionadas ao sexo e ao erotismo eram estabelecidas pelo grupo no qual o sujeito estava inserido. Havia regras e leis que limitavam a intimidade em detrimento da coletividade. Assim, até fins do século XVIII, o termo privado dizia respeito a algo que não pertencia a uma pessoa em particular, mas ao que era familiar e coletivo. Também a palavra erótico, dicionarizada na França, em 1566, não possuía o sentido atual, pois designava o que tinha relação com o amor ou procedia dele.

No Brasil, nos primeiros séculos da colonização, a ideia de privacidade inexistia. O público e o privado se entrecruzavam. Sabia-se de tudo e de todos, como evidenciam as denúncias encontradas nos arquivos da Inquisição. As fechaduras eram caras e as casas, inclusive a dos ricos, não se constituíam em ambientes reservados aos seus moradores. Um telhado baixo, uma fresta na porta ou na janela, uma pequena abertura acidental na parede eram sempre um convite aos bisbilhoteiros. Numa terra em que negras e índias andavam seminuas, seus seios eram vistos apenas como "aparelhos de lactação" e sua nudez era explicada pela pobreza material e cultural em que viviam. Já as mulheres brancas, estas eram mantidas afastadas e vestidas com decoro, o que aumentava a curiosidade e o desejo masculino. Porém, é digno lembrar que a mulher, independente da sua origem social ou étnica, era sempre vista como um "ninho de pecados", uma perdição para homens incautos.

Por meio do Manual do confessor, a Igreja controlava o comportamento dos casais, tornando o casamento algo despido de conteúdo erótico e sexualizado. O caráter sagrado do matrimônio era mantido por interdições: os ósculos (beijos), os tocamentos desonestos (as hoje tão valorizadas preliminares à cópula) e o coito interrompido eram proibidos, afinal, a função do casamento era tão somente a procriação e as práticas sem essa finalidade eram censuradas. A medicina, de mãos dadas com a Igreja, via a paixão como uma doença que causava muitos malefícios, por isso o amor patológico deveria ser tratado com chás, unguentos e alguns tipos de alimentos. 
O rígido controle das práticas sexuais por parte da Igreja enraizava-se lentamente nos confessionários, nas missas e nas visitações da Inquisição. Mesmo assim, não conseguiu acabar com as transgressões que ocorriam, principalmente pelas ações dos homens, que tinham as suas esposas em casa e, fora dessa, possuíam as suas amásias. Assim, uma dupla moral instalava-se e se fortalecia como um traço da nossa cultura, daí porque Mary del Priore adjetiva de hipócrita o século XIX, em cuja primeira década já se anunciava um conjunto de mudanças no cotidiano dos brasileiros, quando da instalação da Corte portuguesa no Rio de Janeiro. Lembremos que não eram nada exemplares os comportamentos de muitos elementos da nobreza e da família real. Assim é que, para a autora, nesse século, vivia-se entre a beataria e a libertinagem e, não raro, confessionários e sacristias de igrejas eram lugares para encontros e a prática do sexo, um ato rápido e parcialmente coberto pelas vestimentas.

Como diz a historiadora, "os médicos, sobretudo os do século XIX, eram fascinados por sexo” (2011, p. 77-78). Numa época em que falar desse assunto era tabu, a ciência médica tinha tal prerrogativa, por lutar contra os chamados "desvios sexuais": homossexualidade, histerismo, ninfomania, dentre outros. Tendo o higienismo e o darwinismo como pano de fundo, os médicos preocupavam-se em cuidar da limpeza nas relações entre os casais, para que estes procriassem filhos saudáveis e bonitos. Como se acreditava que o sexo exigia um esforço imenso e o sêmen extraia o que havia de mais puro no sangue masculino, alguns manuais orientavam a periodicidade das cópulas e o seu tempo de duração. O ideal é que fossem rápidas e cumprissem a função de procriar. A honestidade da mulher era medida pela sua pudicícia e o seu prazer era controlado pelo esposo, o qual, nesse particular, acumulava a tripla função de combinar a reserva espermática, a fecundação vigorosa e evitar a volúpia da parceira.

Apesar dos controles da Igreja e da medicina, não faltavam desvios de tais orientações, motivo pelo qual Mary del Priore destaca a hipocrisia do século XIX. Um século que reprimia o sexo, vigiava a nudez e impunha regras aos casais, mas, por outro lado, era obcecado pelo tema, olhava pelas fendas das portas e liberava os bordéis. O casamento era sagrado, mas traía-se a olhos vistos. As prostitutas, mesmo discriminadas, salvavam a família burguesa, pois, com elas, os jovens poderiam se iniciar sexualmente e liberar as pulsões na idade adulta, coisas que não poderiam fazer no leito conjugal. Além disso, chocando-se com a rígida moral que procurava se instalar, os homens liberavam a sua imaginação por meio de uma nascente literatura pornográfica, escondidas a sete chaves das mulheres.

O século XX inicia-se com as "primeiras rachaduras no muro da repressão”, como intitula o terceiro capítulo do livro. As mudanças tra- 
zidas pela República e pelos ideais da modernidade imprimiram uma nova percepção do corpo, este agora não mais escondido pelo excesso de roupas e véus. A vida urbana exigia um corpo veloz, ágil, leve e que se locomovesse com desembaraço, daí o porquê de os médicos aconselharem a prática de exercícios físicos e de esportes, considerados agora hábitos saudáveis. O culto ao corpo se disseminava com a fotografia e o cinema americano, este apresentando um novo modelo de beleza feminina, segundo o qual a gordura era vista como algo feio e doentio.

No que diz respeito aos homens, a modernidade também alterou seus comportamentos. Como explica a autora, "a palavra tomava o lugar do gesto, a competência se sobrepunha à dominação e a mediação substituía o confronto" (2011, p. 155). Os espaços por eles frequentados também se ampliavam: estádios, escritórios, bares e sindicatos faziam as novas sociabilidades. O cinema também contribuía para que se alimentassem códigos estéticos e estereótipos por meio dos heróis que se viam nas telas.

Para a preocupação de muitos, crescia a “devassidão”. A mulher moderna quebrava tabus ao despir as pernas e outras partes do corpo. No teatro de revista, atrizes eram tidas como meretrizes. A revista $O$ Rio $\mathrm{Nu}$ reunia a pornografia das primeiras décadas do século $\mathrm{XX}$, ao passo que também divulgava remédios contra a impotência masculina e doenças sexualmente transmissíveis. Surgiam os “catecismos”, livros de bolso em cujos quadrinhos era contido todo o universo erótico masculino.

Entretanto, liberação rimava com repressão e vigilância. Conforme a historiadora, novamente a medicina continha os excessos por meio de livros que valorizavam a virgindade e orientavam quanto aos cuidados que os homens deveriam ter na noite de núpcias. Todavia, mesmo que pudor e recato continuassem a distinguir as mulheres honestas das levianas, sabia-se que, nos novos tempos, abortos e doenças venéreas eram constantes. Isso explica o surgimento dos primeiros manuais de educação sexual, na década de 1930. Para os rapazes, esses livros traziam variadas imagens e informações sobre os ditos desvios sexuais e as doenças que eles poderiam causar. Já para as jovens casadoiras, os textos apresentavam propositalmente uma linguagem hermética e divulgavam os valores de antigamente: vergonha diante das coisas de natureza sexual e a função procriadora do casamento. As revistas femininas reforçavam o papel da mulher dentro do casamento ao ensinar receitas culinárias e dicas de como "sustentar" o marido, este, pelo próprio gênero, potencialmente infiel.

As últimas décadas do século XX foram de uma liberação quase total. O nu feminino invadiu as telas do cinema brasileiro por meio das pornochanchadas; as modas minimalistas tomarem conta das ruas e praias por meio das minissaias, dos biquínis, dos calções e do topless; a pílula anticoncepcional liberou da mulher o fantasma da gravidez in- 
desejada; o número de divórcios se ampliou; as relações homoafetivas ganharam espaços; a televisão construiu um novo modelo de mulher, esta liberada, livre das amarras do casamento e que trabalha fora; revistas destinadas ao público feminino passaram a falar abertamente em sexo, orgasmo e fetiches; a literatura pornográfica delimitou seu espaço nas bancas de revistas. Porém, a reação masculina não tardou a chegar e, logo, os crimes passionais ganharam manchetes na imprensa. Maridos matam esposas ao constatarem ou mesmo desconfiarem que estivessem sendo traídos. A "revolução sexual” foi contida pelo risco da AIDS, vista inicialmente como o "câncer gay", mas que, tempos depois, instalava o pânico e levava as pessoas a reavaliar seus hábitos sexuais, estilos de vida, princípios morais e padrões de cultura.

Diante de tantos avanços e recuos, Mary del Priore finaliza o seu livro com uma reflexão sobre o que ganhamos e o que perdemos. Para ela, tivemos uma rápida e profunda fratura nos nossos costumes. Felicidade, amor e prazer tornaram-se obrigatórios. Buscamos incessantemente privacidade e intimidade, mas elas se esvaem nas revistas e nas telas de TV, pois tornamo-nos cada vez mais confessionais, narcisistas e exibidos. Precisamos dizer a todos o quanto somos felizes, amados e realizados sexualmente. Lutamos por independência, mas, contraditoriamente, nos isolados num “canto" que tanto lutamos para conquistar. Não temos nenhuma garantia de relações duradouras, pois o medo de compromissos mais sérios tornou tudo provisório, descartável, instantâneo e fácil de ser substituído.

Por fim, a historiadora nos convida a pensar sobre as nossas práticas. Para ela, somos indivíduos de múltiplas caras: virtuosos e pecadores; liberais e conservadores; permissivos e autoritários; severos com os erros dos outros, mas indulgentes com os nossos; em grupo, politicamente corretos, mas preconceituosos e homofóbicos na intimidade; exigentes dos direitos, mas descumpridores dos deveres; além de outras contradições que marcam as nossas ações no cotidiano.

Baseados em tais considerações, podemos afirmar que as cinco partes que compõem o livro aqui resenhado conduzem-nos não apenas a conhecer os preconceitos e as revoluções por que o nosso país passou no tocante ao comportamento sexual, mas também as permanências de algumas marcas que, há séculos, caracterizaram a nossa moralidade. A tessitura da obra deixa revelar a complexidade do real, impedindo-nos de tecer uma definição apressada, precisa e definitiva da nossa identidade.

Não há, em Memórias Íntimas, uma busca pelo ineditismo no tocante ao tema sexualidade e gênero. Mesmo que Mary del Priore tenha se destacado nos últimos anos como uma referência nacional no tratamento desse assunto, não podemos esquecer que, no Brasil, muito antes dela, Gilberto Freyre já havia feito importantes considerações sobre a 
intimidade dos brasileiros na época colonial. Ademais, em nível internacional, há uma vasta literatura que trata da sexualidade, dos corpos e das transgressões à moral imposta pela Igreja e pelo Estado.

Entretanto, é importante salientarmos que o fato de o tema ser conhecido no interior da academia não desabona a obra em análise, uma vez que, nela, a historiadora procura fazer uma síntese desse assunto e torná-lo mais palatável para o grande público de não historiadores que visa a atingir. A propósito, nesse particular, Mary del Priore tem logrado êxito, pois, mesmo com a sólida formação universitária presente no seu currículo, ela encontrou uma maneira de escrever história que foge da linguagem acadêmica, sem perder o rigor na análise dos documentos de que se utilizou: livros de variadas áreas e épocas, revistas, jornais, filmes, seriados de TV. Para reconstruir os períodos históricos que aborda, a autora faz grande uso de obras literárias escritas por Gregório de Matos, José de Alencar, Machado de Assis, Bocage, dentre outros. Pesquisadora experiente, numa das várias entrevistas que concedeu a programas de televisão, ela afirma que: "O historiador quando vai pesquisar sobre um período, a única maneira dele entrar naquele período é através da literatura. Só lhe é dado o cenário que ele vai estudar através da descrição literária. [...] A literatura tem o papel de andar de mãos dadas com a história”1.

Por conseguinte, com uma linguagem literária e um tema envolvente, Del Priore consegue cativar o leitor, motivo pelo qual o seu livro foi muito bem recebido no mercado de obras de não-ficção, mantendo-se presente entre as obras mais vendidas nesse gênero durante algumas semanas. Aliás, não é demais assinalar o fato de que nunca se leu e se escreveu tanto sobre história. As bancas de revista e as livrarias têm um amplo acervo de obras dessa área do conhecimento, escritas não só por historiadores conhecidos, mas também por jornalistas que analisam o nosso passado e refletem sobre o nosso presente. Tal fato se deve à ampliação das pesquisas no âmbito da denominada História Cultural, que pensa a cultura como um conjunto de significados partilhados e construídos pelo homem para explicar o mundo, como assim define Sandra Pesavento $(2008)^{2}$. Segundo ela, cerca de $80 \%$ da produção historiográfica nacional hoje corresponde a essa corrente da historiografia e não só se expressa nas publicações especializadas.

Ao nos convidar a um voyeurismo historiográfico num museu da sexualidade e do erotismo, Mary del Priore, mais uma vez, opta por buscar o lado humano dos acontecimentos, em vez de se preocupar com datas e nomes de pessoas. Isso, diga-se de passagem, tem sido característico em obras que essa autora tem escrito nos últimos anos, ao revelar, por exemplo, as biografias de indivíduos que, mesmo fazendo parte da elite, são praticamente desconhecidos na nossa história, como são os casos do príncipe Pedro Augusto, neto de D. Pedro II, e de Luísa Margarida 
Portugal e Barros, a Condessa de Barral, uma nobre que fez o nosso segundo imperador doer de paixão ${ }^{3}$.

Podemos concluir que, com Histórias íntimas, mais uma vez, Mary del Priore tece uma história do cotidiano e das sensibilidades, que sempre passaram ao largo da história positivista, tão preocupada em mostrar os feitos dos governantes, e de uma historiografia marxista, de viés ortodoxo, ciosa em interpretar os fatos a partir da esfera econômica, relegando os elementos da "superestrutura” a um plano inferior.

FRANCISCO DAS CHAGAS SILVA SOUZA

Licenciado em História pela Universidade Federal da Paraíba e Doutor em Educação pela Universidade Federal do Rio Grande do Norte, Instituto Federal de Educação, Ciência e Tecnologia do Rio Grande do Norte, Campus Mossoró chagas.souza@ifrn.edu.br 